https://doi.org/10.11646/palaeoentomology.3.2.1

http://zoobank.org/urn:lsid:zoobank.org:pub:D4723086-83E3-45D4-AC27-1F6AD117B28F

\title{
Viruses and insects
}

\author{
JACEK SZWEDO \\ Laboratory of Evolutionary Entomology and Museum of Amber Inclusions, Department of Invertebrate Zoology and Parasitology, \\ Faculty of Biology, University of Gdansk, 59, Wita Stwosza St., PL80-308 Gdańsk, Poland \\ ”"jacek.szwedo@biol.ug.edu.pl; @ https://orcid.org/0000-0002-2796-9538
}

Living under severe confinement and global state of war imposed by the emergence and worldwide very rapid spreading of the viral epidemic of zoonotic origin - coronavirus SARS-CoV-2, the world is yet again experiencing a weird period. The coronavirus disease 2019 (COVID-19) pandemic is the defining global health crisis of our time and the greatest challenge we have faced since World War II, stressing every one of the countries it touches; it is creating devastating social, economic and political crises that will leave deep scars and will undoubtedly change the way we live and interact with each other. The number of known disease-causing viruses have been increasing in the last few decades and this trend is likely to continue. Therefore, it is legitimate to think about the evolutionary effect of viruses and their influence on the processes of organisms.

In the Recent fauna, insects are the world's most diverse group of animals, making up more than 58 percent of the known global biodiversity. With over one million different species of insects described, and current estimates predicting that another 4 million insect species remain unknown, insects are the most exuberant manifestation of Earth's many and varied life forms (Zhang, 2011; Stork et al., 2015; Foottit \& Adler, 2017, 2018; Stork, 2018). The original simple insect body plan has become modified and has survived to produce an enormous variety of species during millions of years of evolution and adaptation to changing environments and other organisms. Insects exploit virtually all terrestrial and freshwater environments on the planet, as well as many brackish waters and even open oceans' surface, where they play major roles in the function and stability of terrestrial and aquatic ecosystems.

Viruses are ubiquitous, obligate intracellular parasites and one of the most abundant biological entities on Earth. Viruses can reproduce only in living cells and, in their simplest form, are composed of a nucleic acid, either DNA or RNA, and a protein shell referred to as the capsid. More complex viruses also contain a lipoprotein envelope (Knipe et al., 2013; Dimmock et al., 2016; Shors, 2017).
The evolutionary history of viruses is difficult to trace because they do not preserve well in the fossil record, being too small and fragile, however the oldest traces of their presence have be found in the Precambrian, Neoproterozoic deposits of the Jiuliqiao Formation in the Huainan region of Anhui Province, China (Lan et al., 2020). Viruses are divided into two broad nontaxonomic categories, the enveloped viruses and the nonenveloped viruses. The formal taxonomic classification of viruses is the responsibility of the International Committee on Taxonomy of Viruses (ICTV) system (ICTV 2019), although the Baltimore classification system (Baltimore, 1971) can be used to place viruses into one of seven groups based on their manner of mRNA synthesis (Shors, 2017; Kuhn, 2020). Specific naming conventions and further classification guidelines are set out by the ICTV.

Interactions between viruses and their insect and other terrestrial arthropod hosts occur at many levels. Since insects play pivotal roles in the biosphere, it can be speculated that insect viruses in general may have radiated through the plant, fungi and animal kingdoms from common insect origins (Thézé et al., 2011). Insects are infected by a diverse medley of viruses - the five most commonly encountered types of insect viruses are iridoviruses, cytoplasmic polyhedrosis viruses, entomopoxviruses, ascoviruses, and baculoviruses (Miller \& Ball, 1998; Resh \& Cardé, 2009; Asgari \& Johnson, 2010). Insects are known as vectors of numerous viral diseases affecting plants, animals and humans. For example, dengue fever, yellow fever, West Nile fever and chikungunya virus are known to be transmitted by the mosquitoes of the genus Aedes Meigen, 1818 (Diptera: Culicidae: Anophelinae: Aedini). However, classification of this genus is still not well established (Wilkerson et al., 2015), and only the (sub) genus Ochlerotatus Lynch Arribálzaga, 1891 is recorded as an inclusion in Eocene Baltic amber (Pielowska et al., 2018). There is no proof that it was a vector, and further work is required to understand the competence for viruses transmission (Blagrove et al., 2016). Characteristics of mosquitoes as 
vectors of viruses and other pathogens still needs to be investigated (Clements, 2012). Spectacular findings, as traces of haemoglobin-derived porphyrins in the Eocene mosquito (Greenwalt et al., 2013) is very important proof of existence of blood-feeding behavior in Culicidae. Culicidae evolution, classification and internal relationships are still subject of debate (Reidenbach et al., 2009; Silva et al., 2019), and fossil records in addition to documenting the existence of extinct species, can often provide information on the behavior and ecology of ancient organisms. The coevolution of viruses with their hosts and vectors depends on the evolution of the hosts and vectors coupled with factors involved in virus evolution. A plant disease is the result of interaction between susceptible host plant, virulent pathogen, and the environment. Insects are the most important vectors of plant viruses and the main or sole means of spread of many plant pathogens. Plant diseases spread by insect vectors can be crucially important to the profitable production of some crops (Resh \& Cardé, 2009; Lefeuvre et al., 2019; Takahashi et al., 2019). Insects, belonging mostly to the order Hemiptera, transmit more than $70 \%$ of known plant viruses (Hogenhout et al., 2008). The aphids, whiteflies, planthoppers, leafhoppers and treehoppers, as well as some mealybugs, thrips and beetles are vectors of economic importance, identified as being able to transmit plant viruses with extraordinary specificity (Resh \& Cardé, 2009; España \& López-Moya, 2014; Subramanya Sastry et al., 2019). Hemipterans are particularly well suited to transmitting plant viruses because of their needlelike mouthparts that they use for sucking sap - phloem or xylem and/or the contents of plant cells. The coevolutionary processes of viruses, their host plants and insect vectors seems to be long (Thézé et al., 2011; Possee \& King, 2014). The fact that insects are evolutionarily older than angiosperms (also than birds or mammals) suggests that they might have had a preeminent importance in the origin and evolution of several plant (and vertebrates) viruses. Complex interactions are reported: viruses can manipulate plants to encourage vectors to feed for longer periods (Dáder et al., 2017) or discourage potential destructive insects (Safari et al., 2019). The oldest hemipterans are known from the Carboniferous (Nel et al., 2013); however, most of viruses are transmitted by much younger phylogenetically groups (e.g., Aphidini, Delphacidae, Deltocephalinae), often rapidly diverged and differentiated in post-Cretaceous times, when angiosperm plants became dominant (Dohlen \& Teulon, 2003; Wu et al., 2008; Zahniser \& Dietrich, 2010; Kim et al., 2011; Hull, 2014; Huang et al., 2017). The requirement of optimum conditions for propagation and the presence of host defense mechanisms force viruses to continually coevolve with the host. The majority of viruses have a narrow natural host range, indicating a high degree of adaptation to the host plant and tight coevolution. In the broader sense, coevolution of viruses and their hosts can be seen as a form of mutualistic symbiosis in that the virus benefits from not compromising the host and the host benefits from not being compromised by the virus (Lovisolo et al., 2003; Gaur et al., 2014; Hull, 2014). As all other organisms, insects are susceptible to many disease-causing viruses. Insects have had to overcome an array of viruses at different points in their life cycle, and viruses have been recorded from a wide range of insects. While there are more than 1,100 reported viruses that infect more than 20 different families of insects, the largest number described to date, over 600 , belong to the family Baculoviridae (Schroeder, 2011; Possee \& King, 2014; Grzywacz, 2017). Recently, deformed wing virus (DWV) has become the most well-known, widespread, and intensively studied honeybee pathogen in the world - due to the arrival and global spread of a new vector, the ectoparasitic mite Varroa destructor Anderson \& Trueman, 2000 (Martin \& Brettell, 2019). The most spectacular example of relationships between viruses and insects - endoparasitoid wasps (some Ichneumonoidea) — is use of polydnaviruses. The "polydnavirus soups" are produced by the calyx gland, being a modified part of the lateral oviduct, present in some Braconidae and Ichneumonidae (Leobold et al., 2018). Polydnaviruses or virus-like particles play a critical role in suppressing the host (prey) immune response at oviposition, so that successful development of the parasitoid can proceed (Whitfield, 1997; Burke \& Strand, 2012; Herniou et al., 2013; Strand \& Burke, 2015, 2019). This association of polydnaviruses with parasitoid wasps is about 100 million years old (Murphy et al., 2008; Herniou et al., 2013; Chen \& van Achtenberg, 2019); and 'domesticated viruses' seems to explain how multidirectional wasp adaptation to different host species. Associations of viruses and insects could be more complicated with endosymbiotic bacteria used as vehicle for transovarial transmission (Jia et al., 2017; Perlmutter \& Bordenstein, 2020). Dramatic episodes of viral infections have challenged and shaped animal evolution for hundreds of millions of years. A fraction of paleoviruses have left unmistakable traces-fossilized versions of themselves-now inherited as part of host genomes. Paleovirology, the study of viruses on evolutionary timescales, can exploit information from these endogenous viral elements (EVEs), which are the result of heritable horizontal gene transfer (HGT) from viruses to hosts. Some of these endogenous viruses are derived from ancient relatives of extant viruses, allowing us to better examine ancient viral host range, geographical distribution and transmission routes (Katzourakis \& Gifford, 2010; Patel et al., 2011; Aswad \& Katzourakis, 2012; Aiewsakun \& Katzourakis, 2015). EVEs derived from a strikingly diverse set of viral lineages, both from RNA and DNA 
viruses, are scattered throughout the genomes of ants and could be playing an important role in ant genomes (Flynn \& Moreau, 2019; Moreau, 2020). Recent data suggest EVEs could represent a deep branch of the insect antiviral defense system (Whitfield et al., 2017; Ballinger \& Taylor, 2019). The discovery of numerous and diverse EVE also reinforces the idea that viruses may serve as vectors of horizontal transfer (HT) of genetic material in eukaryotes (Gilbert \& Cordeaux, 2017; Husnik \& McCutcheon, 2018). Horizontal transfer is the transmission of genetic material between organisms through a mechanism other than reproduction. Over the past hundreds of millions of years, viruses and hosts have been undergoing a continuous co-evolutionary process. Recent evidence suggests that insects have repeatedly acquired genes from symbiotic bacteria that have provided them with key adaptation that has led to their success (Peccoud et al., 2017). The horizontal acquisition of genes for lignocellulose digestion that has led to herbivory in beetles (Wybouw et al., 2016; McKenna et al., 2019). Acquisition of toxin encoding genes that may underlie protection from natural enemies in aphids and vinegar flies (Lynn-Bell et al., 2019; Verster et al., 2019). Several heritable symbionts of insects harbour phage infections, yet the prevalence and roles of phages in heritable symbioses remain poorly understood. A mechanism for gene transfer among various hosts and acquired genes becoming stably inherited elements can have major effects on ecological relationships (Moran et al., 2005; Weldon et al., 2013; Brown et al., 2020).

Insects and their evolutionary tracts have a special role in understanding of viral evolution and how some became pathogens. New viruses that cause diseases often come from animals, as exemplified by the Zika virus transmitted by mosquitoes. Changes in climatic conditions can contribute to the spread of newly introduced viruses and their insect vectors (Ertunc, 2020; Rodríguez et al., 2020). Studies on emergent and reemergent viruses (Ennaji, 2020a, b), evolution and adaptations of their hosts, palaeoentomological investigations on phylogeny and evolution of viruses' insect vectors, is now exemplifying research at the cutting-edge, and critical for supporting the long-term survival of humanity.

\section{References}

Aiewsakun, P. \& Katzourakis, A. (2015) Endogenous viruses: Connecting recent and ancient viral evolution. Journal of Virology, 479-480, 26-37.

https://doi.org/10.1016/j.virol.2015.02.011

Anderson, D. \& Trueman, J. (2000) Varroa jacobsoni (Acari: Varroidae) is more than one species. Experimental \& Applied
Acarology, 24, 165-189.

https://doi.org/10.1023/A:1006456720416

Asgari, S. \& Johnson, K. (Eds) (2010) Insect virology. Caister Academic Press, Norfolk, UK, xii +436 pp.

Aswad, A. \& Katzourakis, A. (2012) Paleovirology and virally derived immunity. Trends in Ecology \& Evolution, 27 (11), 627-636.

https://doi.org/10.1016/j.tree.2012.07.007

Ballinger, M.J. \& Taylor, D.J. (2019) Evolutionary persistence of insect bunyavirus infection despite host acquisition and expression of the viral nucleoprotein gene. Virus Evolution, 5 (2), vez017, 1-9. https://doi.org/10.1093/ve/vez017

Baltimore, D. (1971) Expression of animal virus genomes. Bacteriological Reviews, 35 (3), 235-241. https://doi.org/10.1128/MMBR.35.3.235-241.1971

Bezier, A., Annaheim, M., Herbiniere, J., Wetterwald, C., Gyapay, G., Bernard-Samain, S., Wincker, P., Roditi, I., Heller, M., Belghazi, M., Pfister-Wilhem, R., Periquet, G., Dupuy, C., Huguet, E., Volkoff, A.N., Lanzrein, B. \& Drezen, J.M. (2009) Polydnaviruses of braconid wasps derive from an ancestral nudivirus. Science, 323 (5916), 926-930. https://doi.org/10.1126/science. 1166788

Blagrove, M.S.C., Sherlock, K., Chapman, G.E., Impoinvil, D.E., McCall, P.J., Medlock, J.M., Lycett, G., Solomon, T. \& Baylis, M. (2016) Evaluation of the vector competence of a native UK mosquito Ochlerotatus detritus (Aedes detritus) for dengue, chikungunya and West Nile viruses. Parasites \& Vectors, 9 (452), 1-6. https://doi.org/10.1186/s13071-016-1739-3

Brown, J.J., Mihaljevic, J.R., Des Marteaux, L. \& Hrček, J. (2019) Metacommunity theory for transmission of heritable symbionts within insect communities. Ecology and evolution, 10 (3), 1703-1721. https://doi.org/10.1002/ece3.5754

Burke, G.R. \& Strand, M.R. (2012) Polydnaviruses of parasitic wasps: domestication of viruses to act as gene delivery vectors. Insects, 3, 91-119.

https://doi.org/10.3390/insects3010091

Chen, X.X. \& van Achtenberg, C. (2019) Systematics, phylogeny, and evolution of braconid wasps: 30 years of progress. Annual Review of Entomology, 64, 335-358.

https://doi.org/10.1146/annurev-ento-011118-111856

Dáder, B., Then, C., Berthelot, E., Ducousso, M., Ng, J.C.K. \& Drucker, M. (2017) Insect transmission of plant viruses: multilayered interactions optimize viral propagation. Insect Science, 24 (6), 929-946. https://doi.org/10.1111/1744-7917.12470

Dimmock, N.J., Easton, A.J. \& Leppard, K. (2016) Introduction to modern virology. $7^{\text {th }}$ edition. Blackwell Publishing, Hoboken, New Jersey, 544 pp.

Dohlen, C.D. von \& Teulon, D.A.J. (2003) Phylogeny and historical biogeography of New Zealand indigenous Aphidini aphids (Hemiptera, Aphididae): an hypothesis. Annals of the 
Entomological Society of America, 96 (2), 107-116. https://doi.org/10.1603/0013-8746(2003)096[0107:PAHBON]2.0.CO;2

Ennaji, M.M. (Ed.) (2020a) Emerging and reemerging viral pathogens. Volume 1: Fundamental and basic virology aspects of human, animal and plant pathogens. Academic Press, Boston, Massachusetts, xlii + 1,126 pp.

Ennaji, M.M. (Ed.) (2020b) Emerging and reemerging viral pathogens. Volume 2: Applied virology approaches related to human, animal and environmental pathogens. Academic Press, Boston, Massachusetts, $\mathrm{xxx}+357 \mathrm{pp}$.

Ertunc, F. (2020) Emerging plant viruses. In: Ennaji, M.M. (Ed.), Emerging and reemerging viral pathogens. Volume 1: Fundamental and basic virology aspects of human, animal and plant pathogens. Academic Press, Boston, Massachusetts, pp. 1041-1062.

https://doi.org/10.1016/B978-0-12-819400-3.00046-6

España, M.U. \& López-Moya, J.J. (2014) Interference with insect transmission to control plant-pathogenic viruses. In: Gaur, R.K., Hohn, T. \& Sharma, P. (Eds), Plant virus-host interaction. Molecular approaches and viral evolution. Academic Press, Kidlington, Oxford, UK, pp. 79-103. https://doi.org/10.1016/B978-0-12-411584-2.00004-4

Flynn, P.J. \& Moreau, C.S. (2019) Assessing the diversity of endogenous viruses throughout ant genomes. Frontiers in Microbiology, 10 (1139), 1-13.

https://doi.org/10.3389/fmicb.2019.01139

Foottit, R.G. \& Adler, P.H. (Eds) (2017) Insect Biodiversity: Science and Society, Vol. 1, $2^{\text {nd }}$ Edition. Wiley-Blackwell, West Sussex, UK, xxx $+875 \mathrm{pp}$.

Foottit, R.G. \& Adler, P.H. (Eds) (2018) Insect Biodiversity: Science and Society, Vol. 2. $1^{\text {st }}$ Edition. Wiley-Blackwell, West Sussex, UK, xxxv + 907 pp.

Gaur, R.K., Hohn, T. \& Sharma, P. (Eds) (2014) Plant virus-host interaction. Molecular approaches and viral evolution. Academic Press, Kidlington, Oxford, UK, xxii + 408 pp.

Gilbert, C. \& Coredaux, R. (2017) Viruses as vectors of horizontal transfer of genetic material in eukaryotes. Current Opinion in Virology, 25, 16-22.

https://doi.org/10.1016/j.coviro.2017.06.005

Greenwalt, D.E., Goreva, Y.S., Siljestrom, S.M., Rose, T. \& Harbach, R.E. (2013) Hemoglobin-derived porphyrins preserved in a Middle Eocene blood-engorged mosquito. Proceedings of the National Academy of Sciences of the United States of America, 110 (46), 18496-18500.

https://doi.org/10.1073/pnas.1310885110

Grzywacz, D. (2017) Basic and applied research: Baculovirus. In: Lacey, L.A. (Ed.), Microbial control of insect and mite pests. From theory to practice. Academic Press, Waltham, Massachusetts, pp. 27-46.

https://doi.org/10.1016/B978-0-12-803527-6.00003-2

Herniou, E.A., Huguet, E., Thézé, J., Bézier, A., Periquet, G. \& Drezen, J.M. (2013) When parasitic wasps hijacked viruses: genomic and functional evolution of polydnaviruses. Philosophical Transactions of the Royal Society, B, 368
(1626), 20130051, 1-13.

https://doi.org/10.1098/rstb.2013.0051

Hogenhout, S.A., Ammar El-D., Whitfield, A.E. \& Redinbaugh, M.G. (2008) Insect vector interactions with persistently transmitted viruses. Annual Review of Phytopathology, 46, 327-359.

https://doi.org/10.1146/annurev.phyto.022508.092135

Huang, Y.X., Zheng, L.F., Bartlett, C.R. \& Qin, D.Z. (2017) Resolving phylogenetic relationships of Delphacini and Tropidocephalini (Hemiptera: Delphacidae: Delphacinae) as inferred from four genetic loci. Scientific Reports, 7, 3319. https://doi.org/10.1038/s41598-017-03624-w

Hull, R. (2014) Plant Virology. $5^{\text {th }}$ Edition. Academic Press, Waltham, Massachusetts, xiv+1104 pp.

Husnik, F. \& McCutcheon, J.P. (2018) Functional horizontal gene transfer from bacteria to eukaryotes. Nature Reviews Microbiology, 16 (2), 67-79.

https://doi.org/10.1038/nrmicro.2017.137

International Committee on Taxonomy of Viruses (ICTV 2019). Virus Taxonomy: 2018b Release.

https://talk.ictvonline.org. Email ratification February 2019. Retrieved 16 April 2020.

Jia, D.S., Mao, Q.Z., Chen, Y., Liu, Y.Y., Chen, Q., Wu, W., Zhang, X.F., Chen, H.Y., Li Y. \& Wei T.Y. (2017) Insect symbiotic bacteria harbour viral pathogens for transovarial transmission. Nature Microbiology, 2 (17025), 1-7. https://doi.org/10.1038/nmicrobiol.2017.25

Katzourakis, A. \& Gifford, R.J. (2010) Endogenous viral elements in animal genomes. PLoS Genetics, 6 (11), e1001191, 1-14. https://doi.org/10.1371/journal.pgen.1001191

Kim, H., Lee, S. \& Jang, Y. (2011) Macroevolutionary patterns in the Aphidini aphids (Hemiptera: Aphididae): diversification, host association, and biogeographic origins. PLOS ONE, 6 (9), e24749, 1-17.

https://doi.org/10.1371/journal.pone.0024749

Knipe, D.M., Howley, P.M., Cohen, J.I., Griffin, D.E., Lamb, R.A., Martin, M.A., Rocaniello, V.R. \& Roizman, B. (2013) Fields Virology. Vol. 2. $6^{\text {th }}$ Edition. Lippincott Williams \& Wilkins a Wolters Kluwer Business, Philadelphia, Pennsylvania, 456 pp.

Kuhn, J.H. (2020) Virus Taxonomy. Reference Module in Life Sciences, B978-0-12-809633-8.21231-4. https://doi.org/10.1016/B978-0-12-809633-8.21231-4

Lan, Z., Zhang, S., Tucker, M., Li, Z. \& Zhao, Z. (2020) Evidence for microbes in early Neoproterozoic stromatolites. Sedimentary Geology, 105589.

https://doi.org/10.1016/j.sedgeo.2020.105589

Lefeuvre, P., Martin, D.P., Elena, S.F., Shepherd, D.N., Roumagnac, P. \& Varsani, A. (2019) Evolution and ecology of plant viruses. Nature Reviews Microbiology, 17, 632-644. https://doi.org/10.1038/s41579-019-0232-3

Leobold, M., Bézier, A., Pichon, A., Herniou, E.A., Volkoff, A.N. \& Drezen, J.M. (2018) The domestication of a large DNA virus by the wasp Venturia canescens involves targeted genome 
reduction through pseudogenization. Genome Biology and Evolution, 10 (7), 1745-1764.

https://doi.org/10.1093/gbe/evy127

Lynch Arribálzaga, F. (1891) Dipterologia Argentina [part]. Revista del Museo de la Plata, 1, 345-377.

Lynn-Bell, N.L., Strand, M.R. \& Oliver, K.M. (2019) Bacteriophage acquisition restores protective mutualism. Microbiology, 165, 985-989.

https://doi.org/10.1099/mic.0.000816

Martin, S.J. \& Brettell, L.E. (2019) Deformed wing virus in honeybees and other insects. Annual Review of Virology, 6, 49-69.

https://doi.org/10.1146/annurev-virology-092818-015700

McKenna, D.D., Shin, S., Ahrens, D., Balke, M., Beza-Beza, C., Clarke, D.J., Donath, A., Escalona, H.E., Friedrich, F., Letsch, H., Liu, S.L., Maddison, D., Mayer, C., Misof, B., Murin, P.J., Niehuis, O., Peters, R.S., Podsiadlowski, L., Pohl, H., Scully, E.D., Yan, E.V., Zhou, X., Ślipiński, A. \& Beutel, R.G. (2018) The evolution and genomic basis of beetle diversity. Proceedings of the National Academy of Sciences of the United States of America, 116 (49), 24729-24737. https://doi.org/10.1073/pnas.1909655116

Meigen, J.W. (1818) Systematische Beschreibung der bekannten europäischen zweiflügeligen Insekten. Erster Theil. F.W. Forstmann, Aachen, xxxvi + 332 pp. https://doi.org/10.5962/bhl.title.13731

Miller, L.K. \& Ball, L.A. (1998) The insect viruses. Plenum Press, New York, New York, xvii +413 pp. https://doi.org/10.1007/978-1-4615-5341-0

Moran, N.A., Degnan, P.H., Santos, S.R., Dunbar, H.E. \& Ochman, H. (2005) The players in a mutualistic symbiosis: insects, bacteria, viruses, and virulence genes. Proceedings of the National Academy of Sciences of the United States of America, 102 (47), 16919-16926.

https://doi.org/10.1073/pnas.0507029102

Moreau, C.S. (2020) Symbiosis among ants and microbes. Current Opinion in Insect Science, 39, 1-5.

https://doi.org/10.1016/j.cois.2020.01.002

Murphy, N., Banks, J.C., Whitfield, J.B. \& Austin, A.D. (2008) Phylogeny of the parasitic microgastroid subfamilies (Hymenoptera: Braconidae) based on sequence data from seven genes, with an improved time estimate of the origin of the lineage. Molecular Phylogenetics and Evolution, 47, 378-395. https://doi.org/10.1016/j.ympev.2008.01.022

Nel, A., Roques, P., Nel, P., Prokin, A.A., Bourgoin, T., Prokop, J., Szwedo, J., Azar, D., Desutter-Grandcolas, L., Wappler, T., Garrouste, R., Coty, D., Huang, D.Y., Engel, M.S. \& Kirejtshuk, A.G. (2013) The earliest known holometabolous insects. Nature, 503 (7475): 257-261. https://doi.org/10.1038/nature12629

Patel, M.R., Emerman, M., \& Malik, H.S. (2011) Paleovirology ghosts and gifts of viruses past. Current Opinion in Virology,
1 (4), 304-309.

https://doi.org/10.1016/j.coviro.2011.06.007

Peccoud, J., Loiseau, V., Cordaux, R. \& Gilbert, C. (2017) Horizontal transfer of transposons in insects. Proceedings of the National Academy of Sciences of the United States of America, 114 (18), 4721-4726.

https://doi.org/10.1073/pnas.1621178114

Perlmutter, J.I. \& Bordenstein, S.R. (2020) Microorganisms in the reproductive tissues of arthropods. Nature Reviews Microbiology, 18, 97-111.

https://doi.org/10.1038/s41579-019-0309-z

Pielowska,A., Sontag,E.\& Szadziewski, R. (2018) Haematophagous arthropods in Baltic amber. Annales Zoologici, 68 (2), 237249.

https://doi.org/10.3161/00034541ANZ2018.68.2.003

Possee, R.D. \& King, L.A. (2014) Insect viruses. In: eLS. www.els. net. John Wiley \& Sons, Ltd, Chichester, UK, 1-12. https://doi.org/10.1002/9780470015902.a0020712.pub2

Reidenbach, K.R., Cook, S., Bertone, M.A., Harbach, R.E., Wiegmann, B.M. \& Besansky, N.J. (2009) Phylogenetic analysis and temporal diversification of mosquitoes (Diptera: Culicidae) based on nuclear genes and morphology. BMC Evolutionary Biology, 9 (1), 298-311.

https://doi.org/10.1186/1471-2148-9-298

Resh, V.H. \& Cardé, R.T. (2009) Encyclopedia of Insects. $2^{\text {nd }}$ Edition. Academic Press, San Diego, California, xxxvi +1132 pp.

Rodríguez, V., Lagares, A., Arteaga, H., Mattar, S. \& Ruiz, L.C. (2020) Viral emerging pathogen evolution. In: Ennaji, M.M. (Ed.), Emerging and reemerging viral pathogens. Volume 1: Fundamental and basic virology aspects of human, animal and plant pathogens. Academic Press, Boston, Massachusetts, pp. 35-51,

https://doi.org/10.1016/B978-0-12-819400-3.00003-X

Safari, M., Ferrari, M.J. \& Roossinck, M.J. (2019) Manipulation of aphid behavior by a persistent plant virus. Journal of Virology, 93, e01781-18, 1-10.

https://doi.org/10.1128/JVI.01781-18

Schroeder, D.C. (2011) Viruses of insects. In: Hurst, C.J (Ed.), Studies in viral ecology. Vol. 2: Animal host systems. $1^{\text {st }}$ Edition. John Wiley \& Sons, Inc., Hoboken, New Jersey, pp. 261-271.

https://doi.org/10.1002/9781118025710.ch10

Shors, T. (2017) Understanding Viruses. $3^{\text {rd }}$ Edition. Jones \& Bartlett Learning, LLC, an Ascend Learning Company, Burlington, Massachusetts, 944 pp.

Silva, A.F. da, Machado, L.C., Paula, M.B., Pessoa, C.J.S.V., Bronzoni, R.V.M, Santos, M.A.V.M. \& Wallau, G.L. (2019) Time and mode of Culicidae evolutionary history. BioRxiv, $1-47$.

https://doi.org/10.1101/871145

Stork, N.E. (2018) How many species of insects and other terrestrial arthropods are there on Earth? Annual Review of Entomology, 
63, 31-45.

https://doi.org/10.1146/annurev-ento-020117-043348

Stork, N.E., McBroom J., Gely C. \& Hamilton, A.J. (2015) New approaches narrow global species estimates for beetles, insects, and terrestrial arthropods. Proceedings of the National Academy of Sciences of the United States of America, 112 (24), 7519-7523. https://doi.org/10.1073/pnas. 1502408112

Strand, M.R. \& Burke, G.R. (2015) Polydnaviruses: from discovery to current insights. Virology, 479-480, 393-402. https://doi.org/10.1016/j.virol.2015.01.018

Strand, M.R. \& Burke, G.R. (2019) Polydnaviruses: evolution and function. In: Bonning, B.C. (Ed.), Insect Molecular Virology. Advances and Emerging Trends. Caister Academic Press, Poole, Dorset, UK, pp. 163-181. https://doi.org/10.21775/9781912530083.08

Subramanya Sastry, K., Mandal, B., Hammond, J., Scott, S.W. \& Briddon, R.W. (Eds) (2019) Encyclopedia of plant viruses and viroids. Springer, New Delhi, xxix+2936 pp. https://doi.org/10.1007/978-81-322-3912-3

Takahashi, H., Fukuhara, T., Kitazawa, H. \& Kormelink, R. (2019) Virus latency and the impact on plants. Frontiers in Microbiology, 10 (2764), 1-18. https://doi.org/10.3389/fmicb.2019.02764

Thézé, J., Bézier, A., Periquet, G., Drezen, J.M., \& Herniou, E. A. (2011) Paleozoic origin of insect large dsDNA viruses. Proceedings of the National Academy of Sciences of the United States of America, 108 (38), 15931-15935. https://doi.org/10.1073/pnas.1105580108

Verster, K.I., Wisecaver, J.H., Karageorgi, M., Duncan, R.P., Gloss, A.D., Armstrong, E.E., Price, D.K., Menon, A.R., Ali, Z.M. \& Whiteman, N.K. (2019) Horizontal transfer of bacterial cytolethal distending toxin $\mathrm{b}$ genes to insects. Molecular Biology and Evolution, 36 (10) 2105-2110. https://doi.org/10.1093/molbev/msz146

Weldon, S.R., Strand, M.R. \& Oliver K.M. (2013) Phage loss and the breakdown of a defensive symbiosis in aphids. Proceedings of the Royal Society, B, 280 (20122103), 1-7.

https://doi.org/10.1098/rspb.2012.2103

Whitfield, J.B. (1997) Molecular and morphological data suggest a common origin for the polydnaviruses among braconid wasps. Naturwissenschaften, 34, 502-507.

https://doi.org/10.1007/s001140050434

Whitfield, Z.J., Dolan, P.T., Kunitomi, M., Tassetto, M., Seetin, M.G., Oh, S., Heiner, C., Paxinos, E. \& Andino, R. (2017) The diversity, structure, and function of heritable adaptive immunity sequences in the Aedes aegypti genome. Current Biology, 27 (22), 3511-3519.e7.

https://doi.org/10.1016/j.cub.2017.09.067

Wilkerson, R.C., Linton, Y.M., Fonseca, D.M., Schultz, T.R., Price, D.C. \& Strickman, D.A. (2015) Making mosquito taxonomy useful: a stable classification of tribe Aedini that balances utility with current knowledge of evolutionary relationships. PLOS ONE, 10 (7), e0133602.

https://doi.org/10.1371/journal.pone.0133602

Wu, B.L., Melcher, U., Guo, X.G., Wang, X.F., Fan, L.J. \& Zhou, G.H. (2008) Assessment of the codivergence of mastreviruses with their plant hosts. BMC Evolutionary Biology, 8 (335), $1-13$. https://doi.org/10.1186/1471-2148-8-335

Wybouw, N., Pauchet, Y., Heckel, D.G. \& Van Leeuwen, T. (2016) Horizontal gene transfer contributes to the evolution of arthropod herbivory. Genome Biology and Evolution, 8 (6), 1785-1801.

https://doi.org/10.1093/gbe/evw119

Zahniser, J.N. \& Dietrich, C.H. (2010) Phylogeny of the leafhopper subfamily Deltocephalinae (Hemiptera: Cicadellidae) based on molecular and morphological data with a revised familygroup classification. Systematic Entomology, 35 (3), 489511. https://doi.org/10.1111/j.1365-3113.2010.00522.x

Zhang, Z.Q. (2011) Animal biodiversity: An introduction to higherlevel classification and taxonomic richness. Zootaxa, 3148 (1), 7-12. https://doi.org/10.11646/zootaxa.3148.1.3 